\title{
Original Articles
}

J. Perinat. Med.

1 (1973) 153

\section{Fetal heart rate patterns in labors with intact and with ruptured membranes}

\author{
R. Schwarcz, O. Althabe, R. Belitzky, J. L. Lanchares, R. Alvarez, \\ P. Berdaguer, H. Capurro, J. M. Belizán, J. H. Sabatino, C. Abusleme, \\ R. Caldeyro-Barcia
}

Latin American Center of Perinatology and Human Development Montevideo, Uruguay

Received: April 2, 1973. Accepted May 16, 1973
In previous papers $[1,6]$ it was reported that the rupture of membranes facilitates the production of type I dips in the fetal heart rate (FHR) tracing. This statement is based on the effect of amniotomy on FHR records [6] and also on the quantitative study of a group of 26 monitored labors induced with oxytocin [1], in which membranes were artificially ruptured when cervical dilatation was between 4 and $6 \mathrm{~cm}$ : The incidence of type I dips was significantly higher after amniotomy than before this procedure. The type I dips recorded after rupture of the membranes were attributed to the uneven compression and deformation of the fetal head, or to occlusion of the umbilical vessels during uterine contractions $[1,6,19]$. It was postulated that both effects of uterine contractions were facilitated by the rupture of the bag of waters and corresponding loss of amniotic fluid around the fetal head or the umbilical cord. The design of this previous study [1] did not allow the analysis of the effects of amniotomy independently from the influence of the engagement of the fetal head in the pelvis. The head was usually not engaged from the beginning of labor until the time of amniotomy, whereas it was engaged during most of the period elapsing after rupture of membranes until delivery.

Since engagement increases the pressure received by the fetal head during uterine contractions $[11,19)$, it may facilitate the production of type I dips. The present study was designed prospec-

\section{Curriculum vitae}

RICARDO L. SCHWARCZ, MD: Born in Buenos Aires, Argentina in 1935. Graduated as Doctor of Medicine at the School of Medicine, University of Buenos Aires in 1960. His postgraduate studies in Obstetrics and Gynecology were performed under the direction of his father, Professor Ricardo Scbwarcz.

He received fellowships from the University of Buenos Aires,

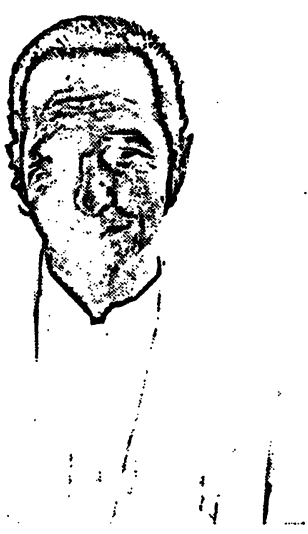
and from the Argentine National Council for Scientific and Technical Research. During 1963 and 1964 be was a fellow at the Service of Obstetrical Pbysiology (Scbool of Medicine, Montevideo, Uruguay) under the direction of Prof. $R$. Caldejro-Barcia.

He taught at the School of Medicine of Buenos Aires. In 1971 be was awarded the degree of Associate Professor of Obstetrics at the University of Rosario, Argentina.

Since 1970, be bas been Consultant of the Pan American Healtb. Organization/World Health Organization at the Latin American Center of Perinatology and Human Development, Montevideo, Uruguay.

tively to allow the analysis of the effects of amniotomy independently from the influence of the engagement of the fetal head. Further information which will be provided by this design, is the FHR pattern throughout labor with intact membranes. At present, this is not available since most obstetricians rupture the membranes artificially before cervical dilatation has reached $6 \mathrm{~cm}$. Furthermore, most of the FHR 
tracings are obtained during labor by means of the fetal scalp electrode which cannot be inserted when membranes are intact.

\section{Methods}

\subsection{Design of the study.}

In one group of labors the bag of waters was not ruptured artificially, ramaining intact until full cervical dilatation had been reached ${ }^{1}$.

In the second group of labors, amniotomy was performed early during the first stage when cervical dilatation was between 4 and $5 \mathrm{~cm}$ ("early amniotomy"). This design allows the comparison of the incidence of type I dips between both groups of labors (intact or ruptured membranes) in two conditions: a) before the fetal head becomes engaged, and b) after head engagement. It also enables to study the influence of the engagement of the head a) within the group of labors with intact membranes, and b) within the group of labors with ruptured membranes.

\subsection{Rupture of the membranes}

The 37 labors are classed in two groups.

Group 1. In 17 labors, artificial rupture of membranes was performed when cervical dilatation was between 4 and $5 \mathrm{~cm}$ ("early amniotomy").

Group 2. In the remaining 20 patients early amniotomy was not performed and the membranes remained intact at least until full cervical dilatation had been reached; during the second stage of labor the membranes either ruptured spontaneously or were ruptured by amniotomy ${ }^{2}$. In two labors of this group the head and shoulders of the fetus were delivered with unruptured membranes.

The decision to perform or not early amniotomy was made at random.

\subsection{Monitoring of labor}

Intrauterine pressure was recorded in all 37 labors during the whole period of study with a catheter introduced via the vagina and cervix into the uterus between the ovular membrane and the uterine wall.

Fetal heart rate (FHR) was recorded simulaneously with intrauterine pressure. When the membranes were intact the signal triggering the tachometer was obtained with the Doppler principle applied to a beam of ultrasounds. After amniotomy, an electrode was inserted into the fetal scalp and the fetal ECG was the trigger signal.

When in a given section of the record the FHR was illegible or unreliable, the whole section was excluded from the study and the corresponding uterine contractions, even if distinctly recorded, were not counted.

1 Those labors in which the membranes ruptured spontaneously before the end of the first stage, were excluded from the analysis.

2 In group 2, the contractions and dips recorded after rupture of membranes in the second stage were not included in this study.

\section{Clinical material}

Thirty seven pregnant women without known complications of pregnancy, with a single living fetus in cephalic presentation and without cephalopelvic disproportion, were studied. Labor started spontaneously at term and progressed without need of any medication (oxytocin, analgesics, etc.). The women were allowed to change their position (supine or lateral) as they wished.

Parity. Seven primigravidae and 10 multiparae constitute the group with early amniotomy. The group with unruptured membranes included 7 primigravidae and 13 multigravidae.

Loop of cord around fetal neck. Such a loop was found in 5 fetuses of the group with early amniotomy and in eleven fetuses of that with intact membranes.

Duration of labor. The time elapsing in each labor from the moment when cervical dilatation reached $5 \mathrm{~cm}$ until delivery of the fetus is illustrated in Fig. 1.

Uterine contractions. No significant difference was found between both groups of labors either in the intensity or in the frequency of uterine contractions [2].

Characteristics of newborn. The birth weight, cephalic perimeter and APGAR scores at 1 and 5

\section{$\Delta$ mean of each group}

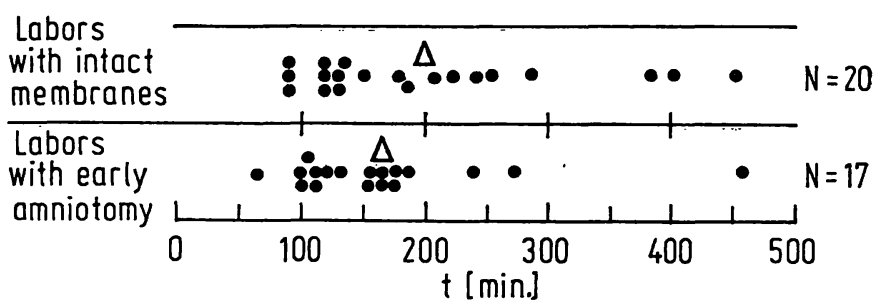

Fig. 1. For each labor, time elapsed from the moment when cervical dilatation reached $5 \mathrm{~cm}$, until delivery of the fetus.

\section{$\Delta$ mean of each group}

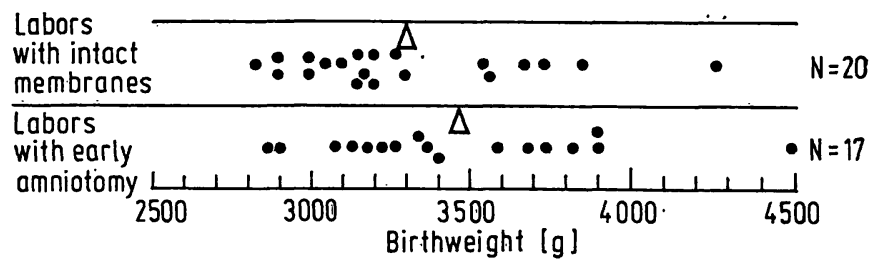

Fig. 2. Birth weight of each newborn in both groups. 


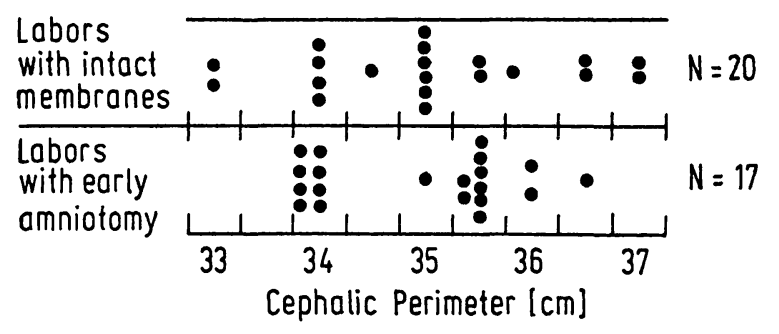

Fig. 3. Cephalic perimeter of each newborn in both groups.

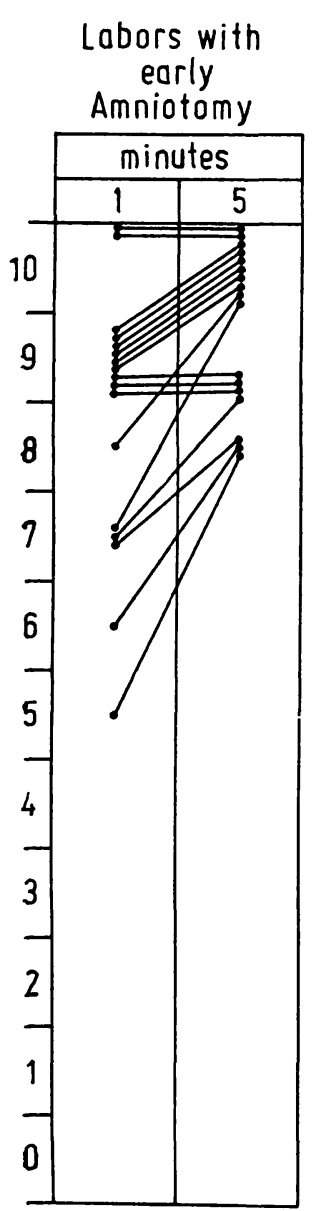

$N=17$

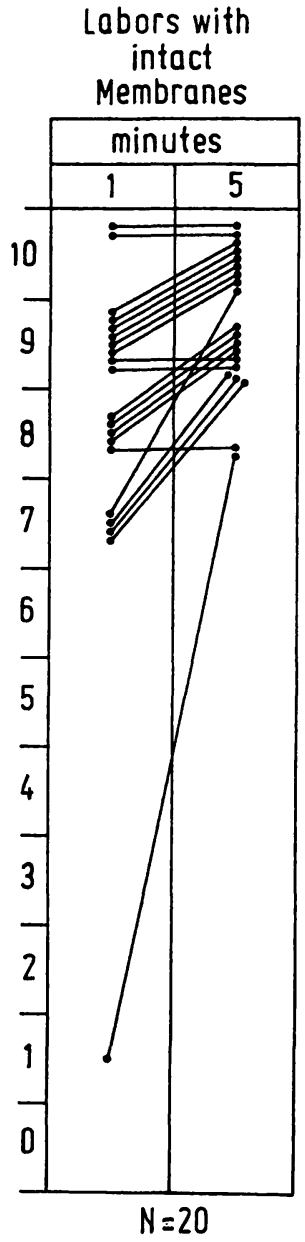

Fig. 4. Apgar score of each newborn in both groups.

minutes are illustrated for each neonate in Figs. 2, 3 and 4.

There is no difference between both groups of labors in the distribution of parity, duration of labor and characteristics of the newborn. The incidence of cord loop was higher in the group with intact membranes than in that with early amniotomy.

\section{Results}

\subsection{Type II dips (late decelerations).}

The overall incidence of type II dips in both groups of labors was very low in agreement with the vigorous condition of the newborns and the absence of complications of pregnancy and labor in these women. Less than $2 \%$ of the uterine contractions recorded in the 37 labors produced type II dips. No significant difference was found in this aspect between the group of labors with intact membranes and that with early amniotomy. Type II Dips will not be further analyzed in this paper.

\subsection{Type I dips ${ }^{3}$.}

The incidence of type I dips was influenced by the status of the membranes and the station of the fetal head. When the membranes remained intact until a few minutes before delivery (Figs. 5 and 6) the incidence of type I dips was null or very low.

When the rupture of membranes occurred with full cervical dilatation and the head was engaged (Fig. 7) a very high percentage of uterine contractions produced type I dips after the rupture.

Type I dips usually appeared after early amniotomy but initially their incidence was low (Fig. 8-A). As labor progressed and the head engaged in the pelvis the incidence of type I dips increased and in some cases came close to $100 \%$ in advanced labor (Fig. 8-B).

\subsubsection{Quantitative study of the incidence of type I dips}

For any given group of labors the incidence of type I dips was calculated as follows. The number of uterine contractions recorded during a given period of labor in all the women of the group was added. The same sort of pooling was made for all the type I dips recorded. The percentage of contractions producing dips in the pool indicated the incidence of dips for the group. This method was employed to calculate the incidence of type I dips in the groups of labors illustrated in Figs. 9, 10, 11 and 12.

3 Type I dips [6] include FHR patterns commonly attributed to the compression of the fetal head and/or the umbilical cord [10]. 


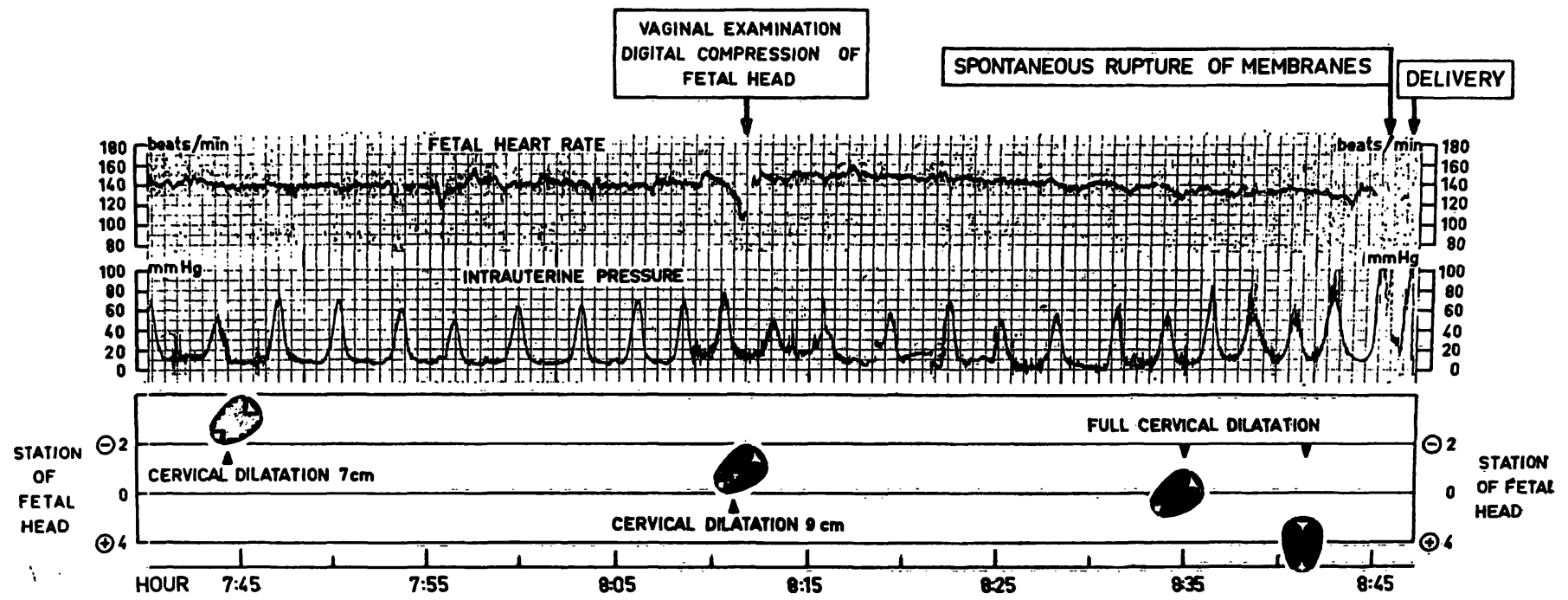

Fig. 5. Labor with intact membranes. Spontaneous rupture of membranes occurred two minutes before delivery. No dips were recorded in FHR until the fetal head became engaged. Three type I dips of small amplitude were seen between hours $8: 25$ and $8: 35$. During vaginal examination at hour $8: 12$ the manual compression of the fetal head caused a transient fall of FHR. At birth no loop of cord was found. Apgar score 8,9 and 10 at 1,5 and 10 minutes.

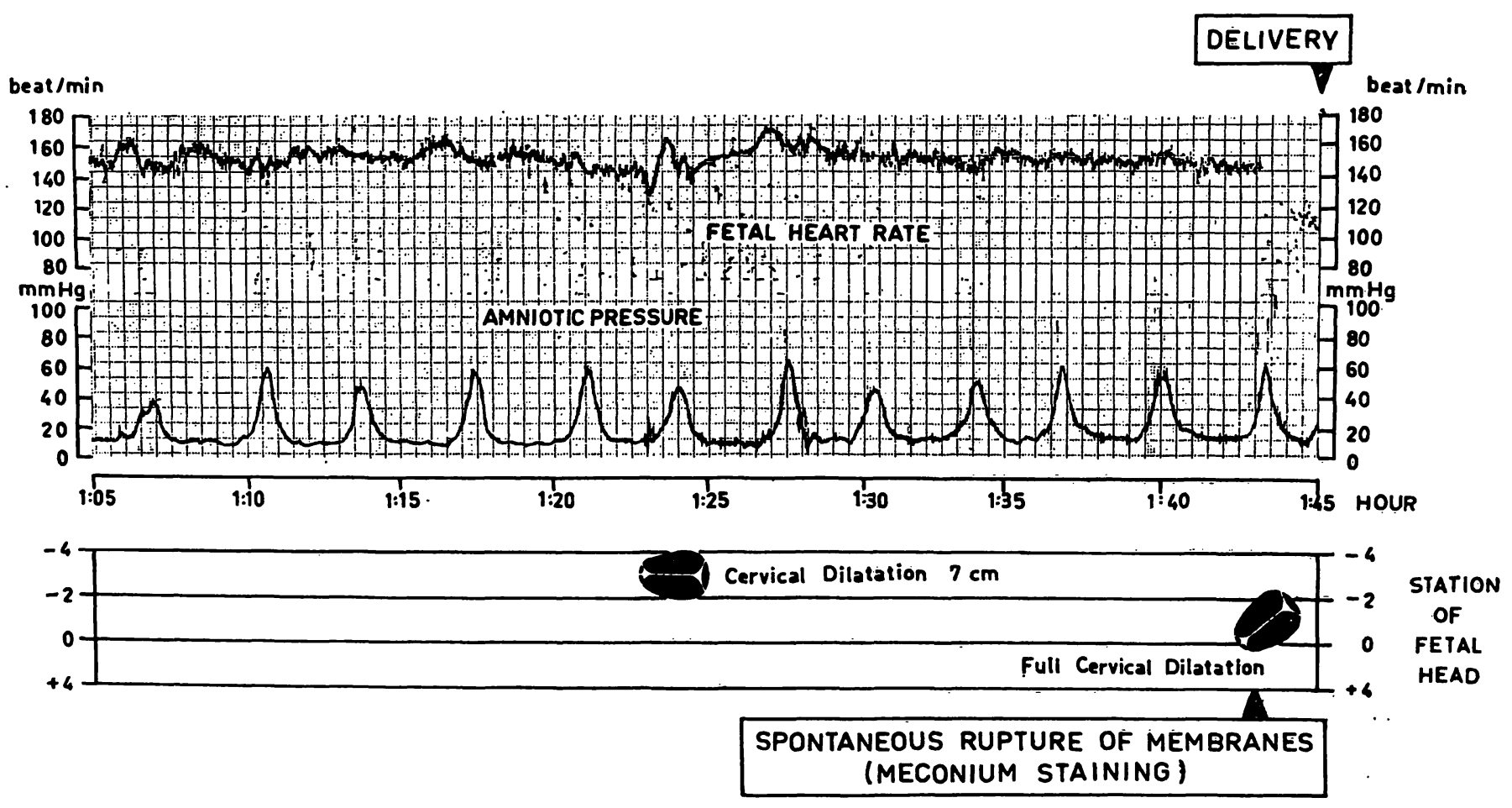

Fig. 6. Labor with intact membranes. Spontaneous rupture two minutes before delivery of the fetus. No dips are seen in the FHR tracing. At birth, one loop of the umbilical cord was found around the fetal neck. Birth weight $2960 \mathrm{~g}$. Apgar score 7,9 and 9 at 1,5 and 10 minutes. 


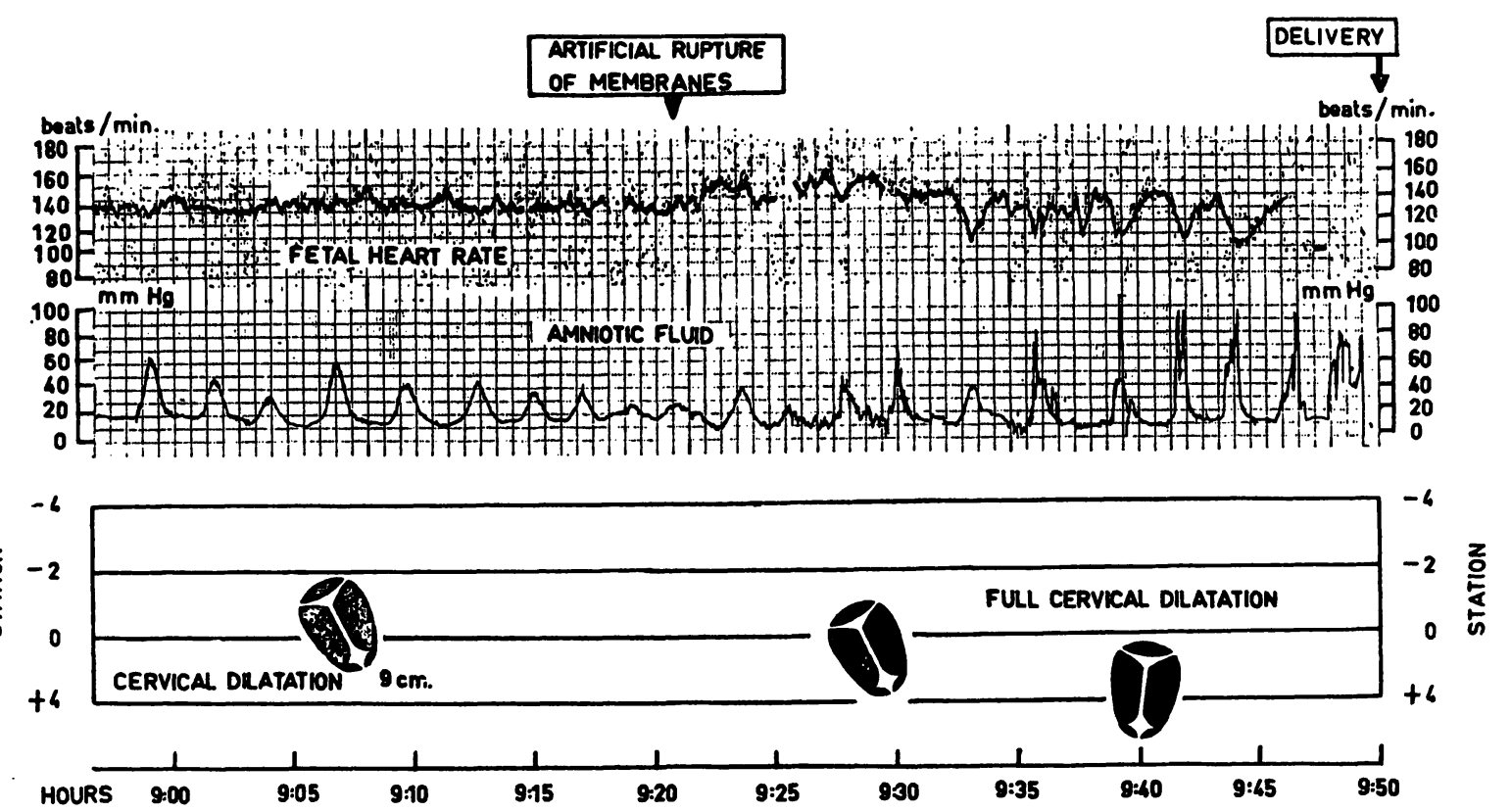

Fig. 7. Record obtained during the last part of the first stage and throughout the second stage of labor. After artificial rupture of membranes, uterine contractions produce type $I$ dips, with little variability in their amplitude and; duration. No loop of cord was observed at birth. Apgar score 8, 9 and 10 at 1, 5 and 10 minutes [After R. Caldeyro-Barcia, R. L. Schwarcz, O. Althabe. Effects of Rupture of Membrane on Fetal Heart Pattern. Intern. J._Gynec. Obstet. 10 (1972) 169].

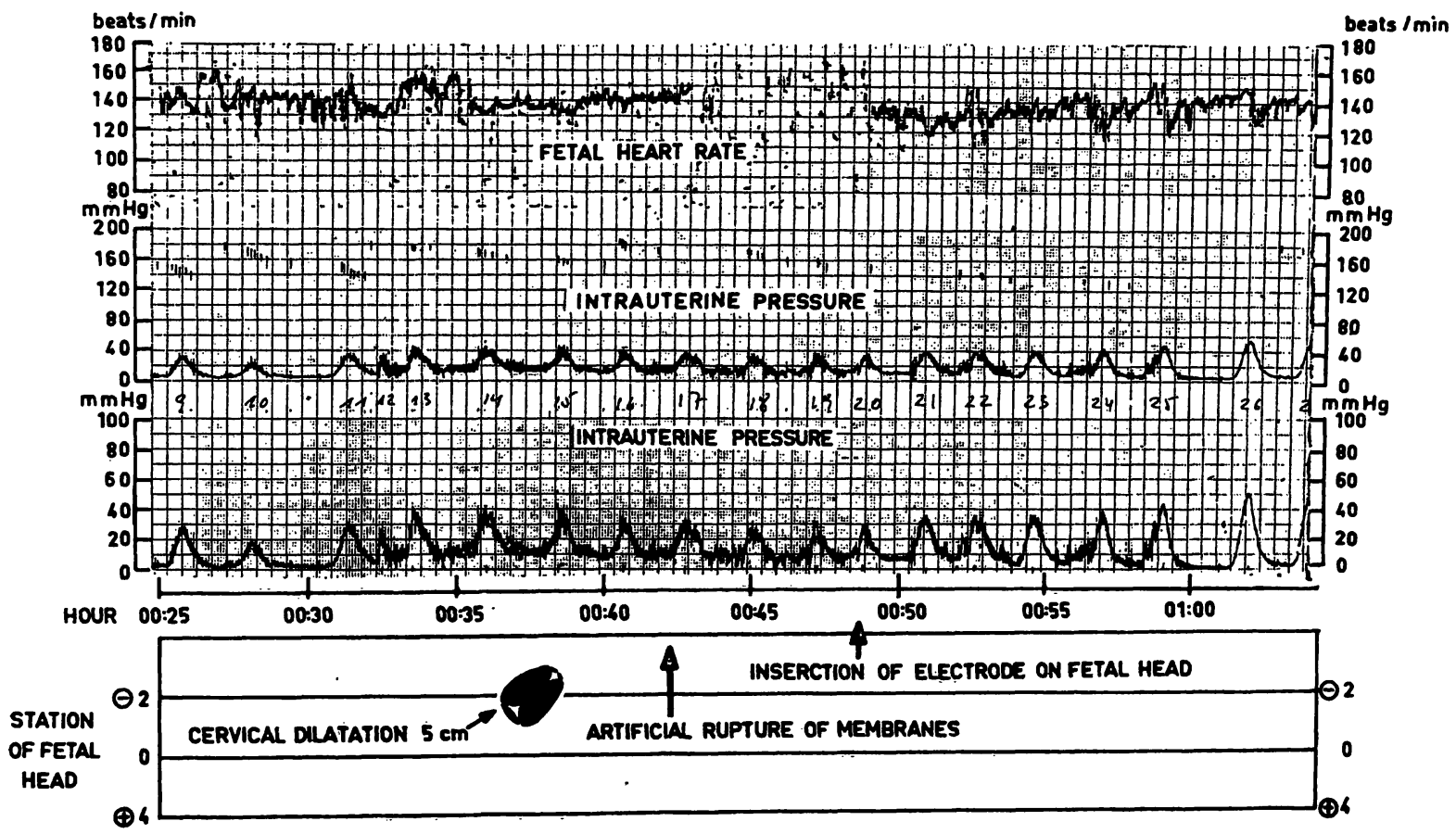

Fig. 8a. Membranes were ruptured artificially at hour $00: 42$ when cervical dilatation reached $5 \mathrm{~cm}$. Fetal head was at minus 2 station in ROP position. After rupture of membranes some uterine contractions produced type I dips whereas others had no effect on FHR. No loop of umbilical cord was present. Continuation of this record is shown in Fig. $8 \mathrm{~b}$. 


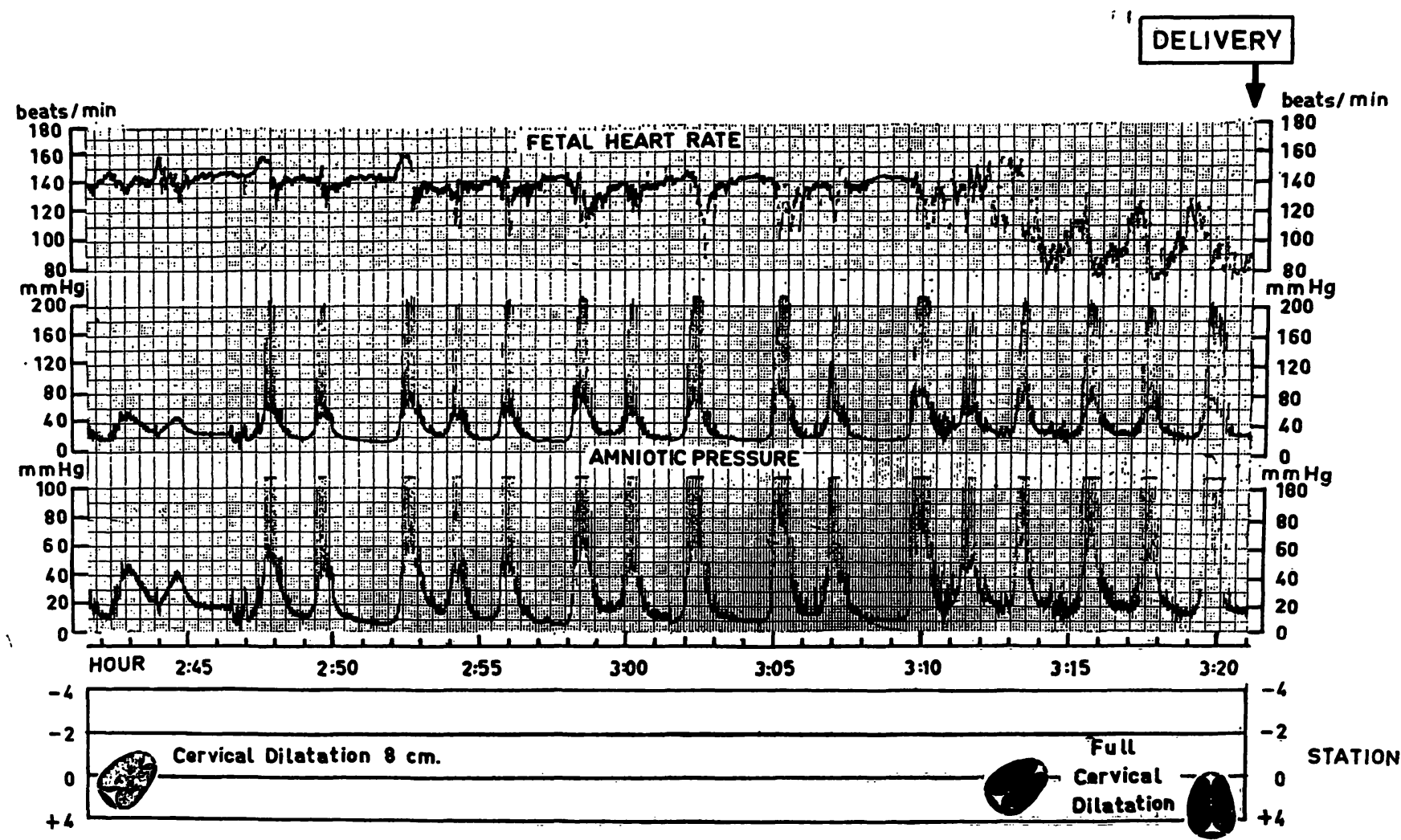

Fig. 8b. Labor with early amniotomy. Continuation of same record shown in Fig. 8a, after 100 minute-interval. At hour $02: 45$ the fetal head was engaged in ROP. After hour $02: 48$ bearing down efforts are superimposed on all uterine contractions. At the peak of these efforts amniotic pressure reached $200 \mathrm{~mm} \mathrm{Hg}$. Each uterine contraction produced a type I dip in FHR. The duration of the dips augmented when the fetal head progressed beyond station 0 . Spontaneous delivery occurred in OS position. No loop of the umbilical cord was found at birth. ApGar score 7, 8 and 9 at 1,5 and 10 minutes.

\subsubsection{Method for statistical analysis}

The non parametric MANN-WHITNEY $U$ test [22] was employed to determine the significance of the differences found between the incidence of dips in different groups of labors (Figs. 9, 10, 11 and 12). This method takes into account the number of labors in the compared groups and also the number of uterine contractions studied.

\subsubsection{Factors analyzed}

The influence of three factors on the incidence of type I dips was analyzed quantitatively:

a. Status of the membranes (intact or ruptured)

b. Station of the fetal head (before or after engagement)

c. Loop of cord around the fetal neck, trunk or limb (present or absent).

\subsubsection{Influence of the status of membranes (intact or ruptured)}

Study made disregarding station of the fetal head. The section of the FHR records analyzed in this study corresponded to the first stage of labor, starting when cervical dilatation was $4-5 \mathrm{~cm}$ and finishing when full dilatation was reached (Fig. 9).

In 20 labors in which the membranes remained intact, the 881 contractions which were recorded during the above mentioned period produced 26 dips. The incidence of dips for this group of labors was $2.95 \%$.

In 17 labors with early amniotomy 745 contractions were recorded in the study period and produced 156 dips. The incidence of dips for this group was $20.95 \%$.

The incidence of type I dips was significantly lower $(p<0.001)$ in the group of labors with intact membranes $(2.95 \%)$ than in that with ruptured membranes $(20.95 \%)$.

Study made taking into account the station of fetal head

Before engagement of the fetal head (station -4 to -1 ). Fig. 10-A shows that in 20 labors 


\begin{tabular}{|c|c|c|}
\hline Membranes & $\begin{array}{c}\text { Intact } \\
\text { till second } \\
\text { stoge }\end{array}$ & $\begin{array}{l}\text { Ruptured } \\
\text { early in } \\
\text { first stage }\end{array}$ \\
$\begin{array}{c}\text { Percent } \\
\text { Incidence } \\
\text { of } \\
\text { Type I } \\
\text { Dips }\end{array}$ & \\
\hline
\end{tabular}

Fig. 9. The incidence of type I dips was significantly higher in labors in which membranes had been ruptured in the first stage than in those where membranes remained intact until the second stage. Results correspond to the first stage of labor from the time when cervical dilatation reached $5 \mathrm{~cm}$ until full cervical dilatation.

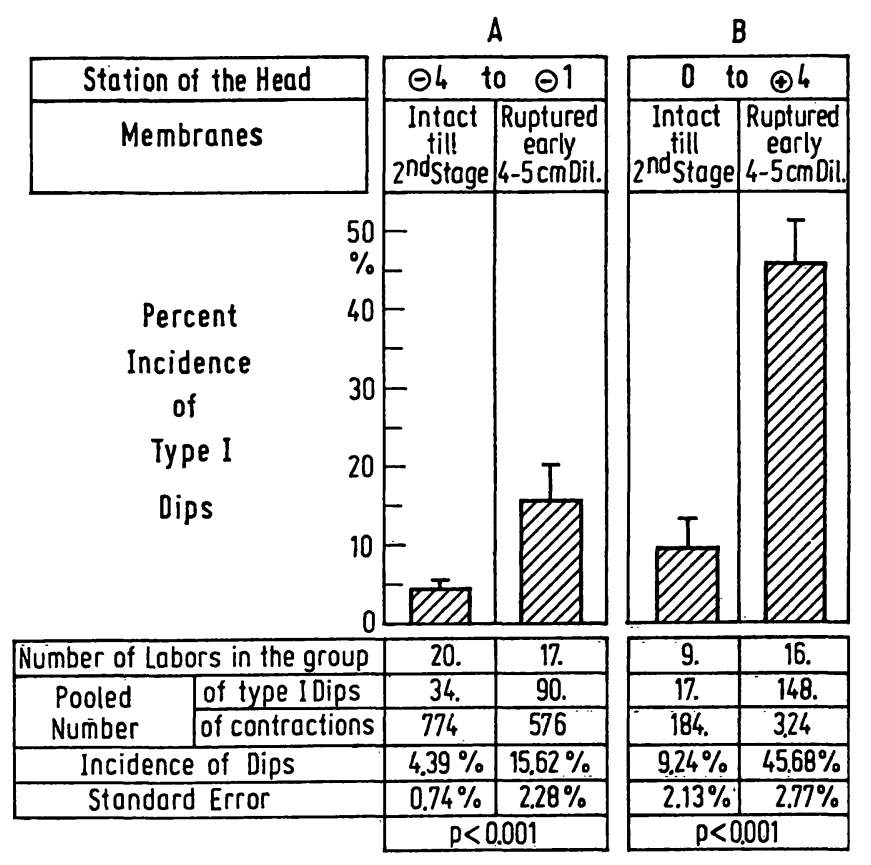

Fig. 10. The incidence of type I dips was higher in labors with early rupture of membranes than in those with intact membranes. This statement holds correct both when the fetrl head has not yet become engaged (station minus 4 to minus 1) (A) and when it was engaged (station 0 to plus 4) (B). with intact membranes the incidence of dips (4.39\%) was significantly lower than in 17 labors with early amniotomy (incidence of dips = $15.62 \%$ ).

After engagement of the fetal head (station 0 to +4$)$. Fig. 10-B shows that in the group of 16 labors with early amniotomy the incidence of dips $(45.68 \%$ ) was significantly higher than in the group of 9 labors in which, after head engagement, the membranes still remained intact (incidence of dips $=9.24 \%$ ).

The results illustrated in Fig. 10 indicate that the presence of intact membranes reduced the incidence of type I dips both before and after engagement of the fetal head. Furthermore, this protective effect of intact membranes was more marked after the fetal head had become engaged (Fig. 10-B) than before engagement (Fig. 10-A).

\subsubsection{Influence of the station of the fetal head (before or after engagement)}

With early ruptured membranes. Fig. 11-B shows that after engagement of the fetal head the incidence of dips (45.68\%) was significantly greater than before engagement $(15.62 \%)$. This result indicates that, with ruptured membranes, engagement of the fetal head markedly facilitated the production of type I dips.

The 17 labors shown in Fig. 11-B before engagement were the same 17 labors with ruptured membranes shown in Fig. 9. In Fig. 11-B, after engagement only 16 labors were analyzed since in one the FHR record became illegible in that period.

With intact membranes. Figure 11-A shows that the incidence of dips was $4.39 \%$ before engagement of the head and that it increased to $9.24 \%$ after engagement. This difference in the incidence of dips before and after engagement is not significant, in keeping with the above postulated protecting effect of the intact membranes.

The group with intact membranes in Fig. 11-A included the same 20 labors presented in Fig. 9. All 29 labors were analyzed for the period before engagement in Fig. 11-A. Only 9 of 20 labors could be analyzed in the period after engagement (Fig. 11-A) since in the other 11 labors the membranes ruptured during that period. 


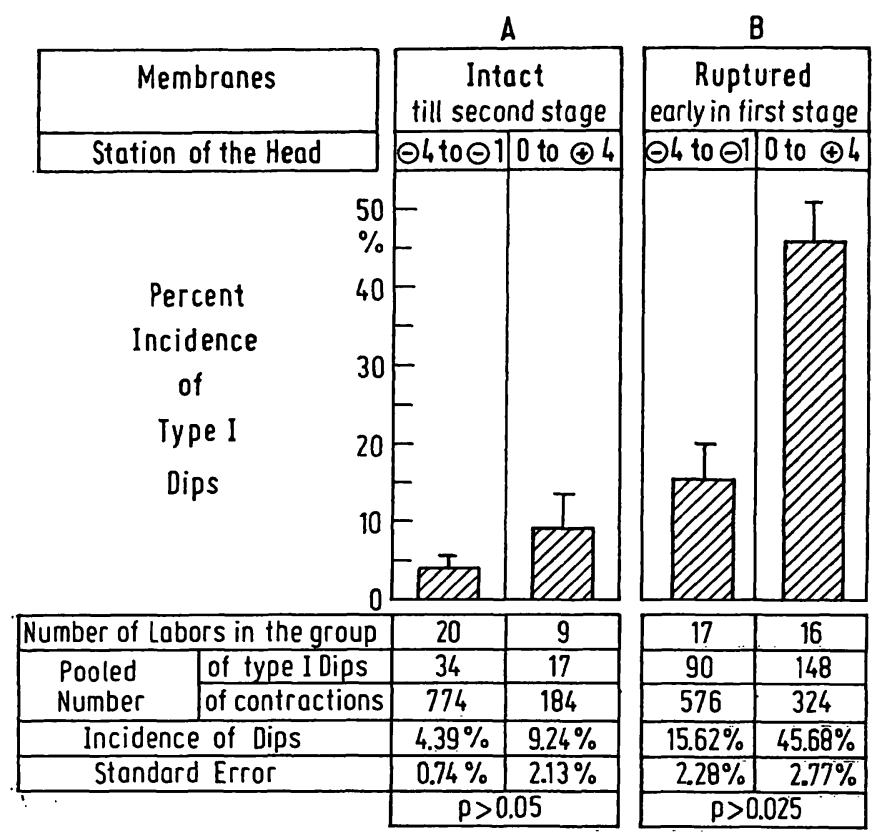

Fig. 11. The incidence of type I dips was higher when the head was engaged (station 0 to plus 4 ) than before engagement (station minus 4 to minus 1 ). The difference was not significant when the membranes remained intact until the second stage of labor (A). It was significant when the membranes were ruptured early in the first stage of labor (B).

\subsubsection{Influence of a loop of cord around the fetal neck (present or absent) (Fig.12).}

The influence of cord loops was analyzed in the section of FHR records corresponding to the first stage of labor, starting when cervical dilatation was $4-5 \mathrm{~cm}$ and ending when full dilatation had been reached. The station of the head was not taken into account in the study.

With intact membranes the incidence of dips was very low (Fig. 12-A); there is very little and not significant difference between the group of 9 labors without cord loop (incidence of dips = $2.06 \%$ ) and the group of 11 labors with cord loop (incidence of dips $=3.66 \%$ ).

With ruptured membranes (Fig. 12-B) the incidence of dips was higher in the group of 5 labors with cord loop (incidence of dips $24.82 \%$ ) than in that of 12 labors without cord loop (incidence of dips $20.06 \%$ ). The difference is not significant $(p>0.05)$. This result should be considered with caution since there were only 5 labors in the group with cord loop.

According to the results illustrated in Fig. 12 the presence or absence of cord loop has no significant influence on the incidence of type I dips.

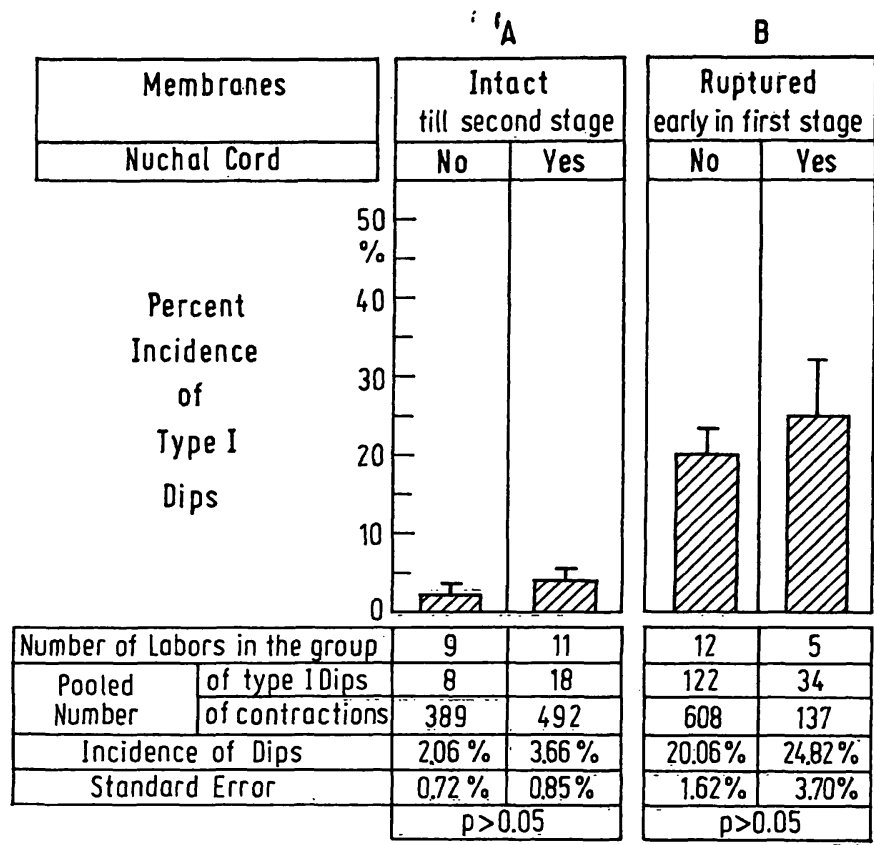

Fig. 12. There was no significant difference in the incidence of type I dips between fetuses with a loop of cord around the neck and those without a cord loop. This statement is true both for labors with intact membranes (A) and with early rupture of membranes (B).

This statement holds true both in labors with intact membranes (Fig. 12-A) and for labors with ruptured membranes (Fig. 12-B). The present results, obtained in labors which started spontaneously and progressed without oxytocin, differ from those obtained by the same authors [1] in a larger group of labors induced with oxytocin infusion. In that study, after amniotomy the incidence of type I dips was significantly higher in the group of 13 labors with cord loop (incidence of dips $=39.16 \%$ ) than in that of 13 labors without cord loop (incidence of dips $=$ $28.18 \%$ ).

\section{Discussion}

The results presented in this paper indicate that in uncomplicated pregnancies in which labor started spontaneously at term and progressed without medication, as long as the ovular membranes remained intact, uterine contractions usually did not produce dips (transient decelerations) in the FHR tracing. Two factors increased the incidence of type I dips: a) the rupture of the ovular membranes; b) the engagement of the fetal head beyond station 0 . 


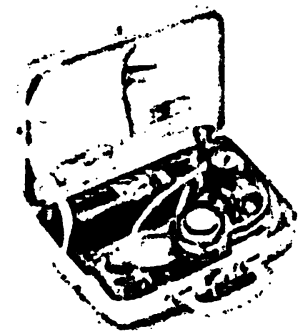

Alternating Pressure Respirator for New-Born Babies (according to Saling)

\section{THEAUER WB66 BRINGS YOU UP TO DATE WTH PERINATALMEDICINE}

When reanimating asphyxia new:orns a rapid insufflation of oxygen $s$ indicated. This can be done with ur alternating pressure respirator, yhich helps you in treating hypoxia ind acidosis of newborns.

The respirator is called WB 66 and s built according to Prof. Saling. i is easy and safe in its applicationxuch more so than the WB 58 from vhich we developed it. The WB 66
Please send me your technical leaflet for the AUER WB 66

Name

Company

Street

City Zip code

Auergesellschaft $\mathrm{GmbH}$, Medizintechnik D1 Berlin 65, Friedrich-Krause-Ufer 24-34 ensures a full-fledged endotracheal respiration with oxygen or air under alternating pressure. The unit is so handy that you may take it along. This is only one of its advantages. What else is new with the AUER WB 66 our technical leaflet will tell you. Just mail us the coupon.

\section{We protect people and} their work. 


\section{$\mathrm{pH}$ Meters for micro-blood tests by the Saling-Turowski method for the exact obstetric diagnosis}

Direct application in the labour-room.

Digital display

$\mathrm{pH}$ range $\mathrm{pH} 0-14$

Resolution $0.01 \mathrm{pH}$
Measuring accuracy $\pm 0.005 \mathrm{pH}$

Test volume $0.05 \mathrm{ml}$

Time required for

the complete measurement $1 \mathrm{~min}$.

Warranty 3 years
ST 4 for the measurement of the actual $\mathrm{pH}$ value

DM 5100

ST 5 with balance device

for the measurement of the actual and metabolic acidity

DM 6000

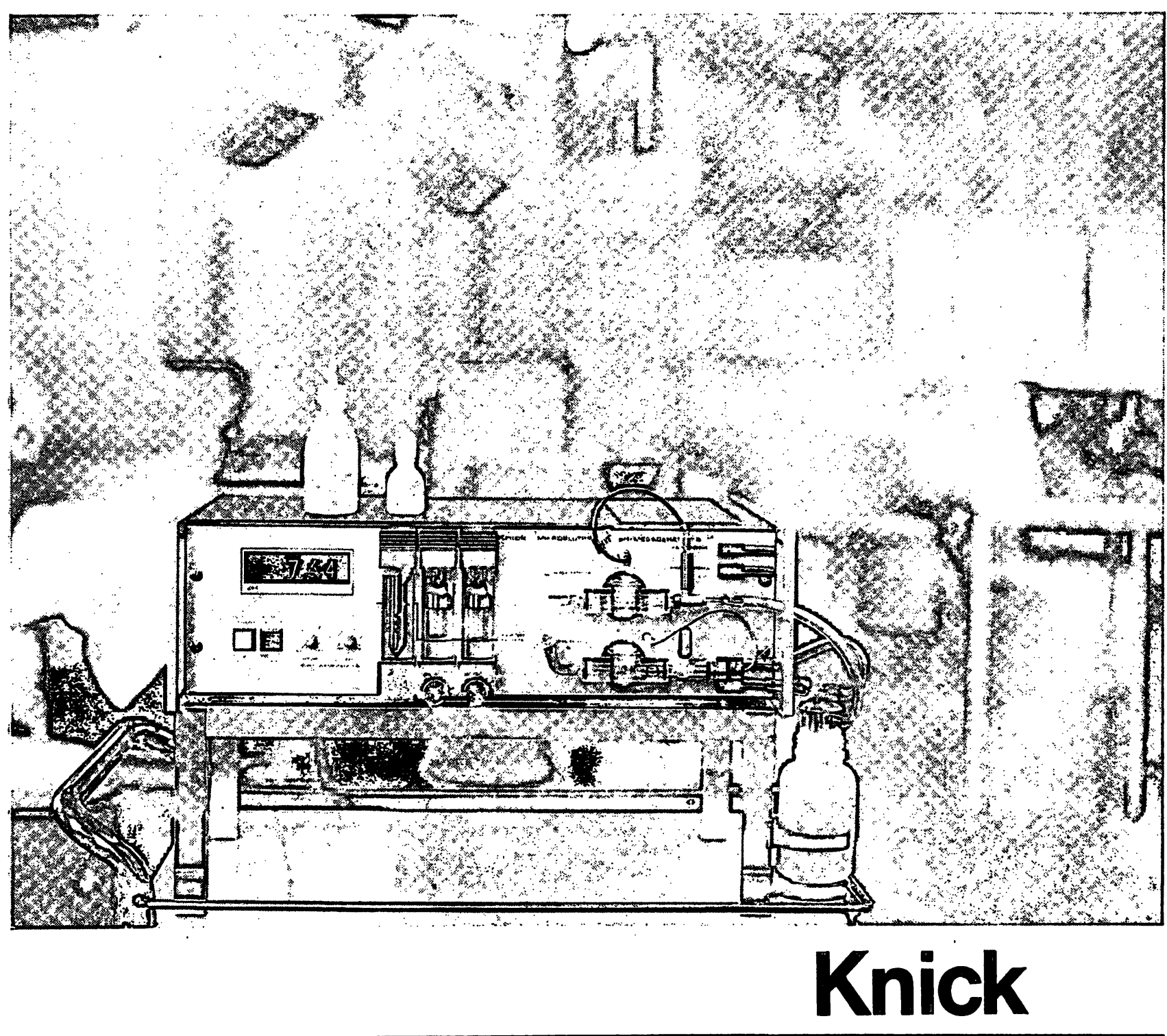




\section{Walter de Gruyter Berlin-New York}

\section{Zeitschrift}

für Klinische Chemie und Klinische Biochemie

Journal of Clinical Chemistry and Clinical Biochemistry

Organ der Deutschen Gesellschaft für Klinische Chemie

Responsible Editors:

Joachim Brugsch, Johannes

Büttner, Ernst Schütte

Edited with the collaboration of numerous german

and foreign experts

12 issues per annum

Appr. 768 pp. DM 290,-; $\$ 127.00$

1973: Vol. 11

\section{Hoppe-Seyler's}

\section{Zeitschrift}

\section{für Physiologische Chemie}

Edited by $A$. Butenandt,

F. Lynen, G. Weitzel

With the collaboration of numerous experts.

12 issues per annum

DM 480,-; $\$ 217.00$

1973: Vol. 354
Edward Muntwyler

Elektrolytstoffwechsel und Säure-BasenGleichgewicht

Translated from the English by

Wolf-Dieter Thomitzek.

1973. 272 pp. 33 illus.

Boards DM 14,80; $\$ 6.45$

ISBN 3110039508

(Sammlung Göschen 7137)

\section{Hilde Götz}

Immunologische

PlasmaproteinDiagnostik

1973. XII +240 pp. 106 illus. Bound DM 96,-; $\$ 41.80$ ISBN 3110037726

\section{Hilde Götz}

\section{Antigenität von} Tumorproteinen

1972. XII +126 pp. With 19 illus. and 6 charts.

Bound DM 60,_; $\$ 26.10$

ISBN 3110040522
Fischer-Werner

Autoradiography

1971. $X+199$ pp. With 93 fig. and 14 tables.

Bound DM 64,-; $\$ 27.90$

ISBN 3110035235

(Working Methods in Modern Science)

\section{Karl Höll}

\section{Water}

Examination - Assessment Conditioning - Chemistry Bacteriology - Biology with the collaboration of Helmut Peter and Dietrich Lüdemann Translated from the 5th German edition by M. R. F. Ashworth. 1972. XVIII + 389 pp. With 24 diagrams and 129 figures. Bound DM 76,-; $\$ 33.10$ ISBN 3110037289 
The combined action of both factors caused the highest incidence of type I dips.

BERDAGUER et al. [2] have shown that there is no significant difference in the intensity of uterine contractions between the group of labors with early amniotomy and that with intact membranes. The higher incidence of type I dips in the first group cannot thus be explained by stronger uterine contractions. A different mechanism of action such as a protective effect of the intact bag of waters may be postulated.

Type I dips are the result of stimulation of the fetal vagus [13] which may be caused by the uneven compression of the fetal head with the consequent cephalic deformation [19] or by umbilical occlusion $[1,6]$. Both effects of uterine contractions are facilitated by the rupture of the bag of waters $[1,6,11,19]$ and as is shown in this paper, by engagement of the fetal head.

In animals it has been demonstrated that during fetal head conpression, cerebral blood flow and oxygen availability to the brain diminish [14] whereas intracranial pressure increases. At the same time, a slowing in fetal EEG was observed [12]. In human fetuses, similar changes in the EEG were recorded during labor with ruptured membranes [7]; these EEG changes coincided with the peak of uterine contractions that caused type I dips in FHR tracing.

FEDRICK and BUTLER [8] found that the incidence of cerebral birth trauma (subdural hemorrhage associated with lacerations of the falx, tentorium or great cerebral vein) increased with the length of time between rupture of membranes and delivery. Marked cephalic deformation and severe brain damage in the newborn demonstrated by necropsy, has been attributed by P. SchwarTz [21] to the absence of an intact bag of waters during labor. The results from the first 215 labors analyzed in the Latin American Collaborative Study [20] indicate that the head of neonates born from labors with intact membranes show less overlapping of parietal bones and a lower incidence of caput succedaneum than neonates born of labors in which early amniotomy was performed.

Muller et al. [15] found that incidence of mental retardation was significantly lower in children born from labors in which membranes were not ruptured until delivery than in children in whose labors membranes were ruptured some hours before delivery.

In view of the findings reported in this paper and those of the bibliography herein reviewed it seems advisable to reevaluate the common obstetrical practice of rupturing membranes artificially early in the first stage of labor as a routine procedure. Particularly since the view that early amniotomy significantly shortens the duration of labor $[3,17,23]$ has not been confirmed by other investigators $[9,18,20]$.

Even if early amniotomy would actually shorten the duration of labor, the benefits for the child are questionable. NiswaNDER and Gordon [16] have reported that in multiparae the lowest incidence of children with neurological abnormalities at one year of age, corresponds to labors in which the duration of the first stage ranged between 11 and 15 hours. When the duration of the first stage was less than 11 hours, or more than 15, the incidence of neurological abnormalities at one year of age increased.

Nowadays the graphic recording of FHR may be obtained by external methods (ultrasounds, phonocardiography) not requiring amniotomy. Monitoring of the fetus during labor can be performed with intact membranes. However if suspicious signs of fetal anoxia and acidosis (type II dips, variable dips or type I dips lasting more than 30-40 seconds) should appear in the FHR tracing, the artificial rupture of membranes would be justified to obtain samples of fetal scalp blood; after amniotomy an electrode can be inserted into the fetal scalp for easier and better recording of FHR.

More research work should be performed to establish which are, if any, the long-term consequences on the central nervous system of the child, of the uneven compression and deformation of the head, which apparently is facilitated by the rupture of membranes $[1,6,19,20,21]$. Similarly, to verify the consequences of temporary occlusion of umbilical vessels during uterine contraction, which could also be facilitated after amniotomy, particularly in those fetuses with a loop of cord around the fetal neck or body $[1,6]$.

Finally, BrotanEk et al. $[4,5]$ have shown that amniotomy produced a long lasting reduction 
of uterine blood flow. All these effects should increase the incidence of type II dips in FHR. However, since the women studied in the present paper had no pregnancy complications, which could potentiate the reduction of uterine blood flow caused by amniotomy, the incidence of type II dips was equally low (less than $2 \%$ ), both in

\section{Summary}

It is known that the production of type I dips by uterine contractions is significantly greater after amniotomy than before this procedure $[1,6,19]$. Type I dips are attributed to the uneven compression of the fetal head or to the transient occlusion of umbilical vessels during uterine contractions.

The purpose of this paper is to establish the pattern of FHR throughout labor when the membranes remain intact until the second stage, and to compare the incidence of type I dips during advanced labor (cervical dilatation greater than $5 \mathrm{~cm}$ ) between women with intact membranes and others with ruptured membranes.

The study is made in 37 pregnant women without known complications and in whom labor starts spontaneously at term and progresses without need of oxytocic, analgesic or other drugs. In 17 of these labors, the membranes are ruptured artificially when cervical dilatation reaches $5 \mathrm{~cm}$ (early amniotomy). In the other 20 labors membranes remain intact at least until full cervical dilatation is obtained. The decision to perform early amniotomy is made at random. In all 37 labors intrauterine pressure and fetal heart rate (FHR) are graphically recorded. When membranes are intact, FHR is recorded by means of ultrasound. There are no significant differences between both groups of labors in the duration of labor (Fig. 1), and in birthweight, cephalic perimeter and Apgar score of the neonates (Figs. 2, 3, 4).

The incidence of type I dips in a given group of labors is expressed by the percentage of uterine contractions which produced type I dips. For this calculation all the contractions recorded in the several labors of the group are pooled together. The significance of the difference in the incidence of type I dips between two groups is determined by a nonparametric statistical test.

The incidence of type I dips is low or nil when the membranes remain intact until a few minutes before delivery (Figs. 5 and 6). If the rupture occurs late, when the fetal head is engaged, a high incidence of type I dips is recorded after the rupture (Fig. 7). After early amniotomy, made before head engagement, the incidence of type I dips is low (Fig. 8-A); as the head engages the incidence increases (Fig. 8-B).

The influence of three factors on the incidence of type I dips is analyzed quantitatively: 1) Status of the membranes (intact or ruptured); 2) station of the fetal head (before the group of labors with intact membranes and with early amniotomy. This ischemic effect of amniotomy on IVS blood flow may produce clear fetal consequences in pregnancies affected by diseases which chronically reduce IVS blood flow (such as toxemia, etc.).

or after engagement), and 3) loop of cord around the fetal neck (present or absent).

During the first stage of labor (Fig. 9) the incidence of type I dips is significantly lower in the group of labors with intact membranes (3\%) than in that with early amniotomy (21\%). This result agrees with the hypothesis that the bag of waters protects the fetal head from the uneven compression received during uterine contraction. A similar result is found when the incidence of type I dips is studied in the period of labors before engagement of the head (Fig. 10-A) and also in the period after engagement (Fig. 10-B). In both conditions the incidence of type I dips is significantly lower in labors with intact membranes than in those with early amniotomy. This finding suggests that the protective effect of the bag of waters is present both before and after head engagement. In the group of labors with ruptured membranes, the incidence is significantly higher after the head is engaged than before engagement (Fig. 11-B) indicating that in absence of the bag of waters the engagement greatly facilitates the production of type $I$ dips. A similar comparison made in the group of labors with intact membranes shows no significant difference before and after engagement of the head, confirming the protection provided by the unruptured membranes even when the head is engaged (Fig. 11-A).

No significant influence of a loop of cord around the fetal neck on the incidence of type $I$ dips is found in either group (Fig. 12).

The incidence of type II dips ("late deceleration", 10) is very low (less than $2 \%$ ) in all groups, in keeping with the excellent condition of all neonates. Type II dips are not further analyzed in this paper.

Evidence obtained from clinical observations $[1,6,13$, $19,20]$ indicates that type I dips may be associated with the uneven compression and deformation of the fetal head, which may cause EEG alterations [7], cerebral birth trauma (21) and neurological sequelae [15]. Experimentation in animals $[12,14]$ shows that compression of the fetal head reduces cerebral blood flow and oxygen availability to the brain, altering the EEG and increasing vagal tone with the consequent rapid fall in FHR.

All these facts make it advisable to reevaluate the common obstetrical practice of rupturing membranes artificially early in the first stage of labor,; as a routine procedure in the management of labor.

Keywords: Bag of waters, compression of fetal head, dips - early and late, fetal heart rate, labor - monitoring of, nuchal cord, rupture of membranes, uterine contractions. 


\section{Zusammenfassung}

Fetale Herzfrequenzmuster unter der Geburt bei intakter und bei gesprungener Fruchtblase

Es ist bckannt, daß Dips vom Typ 1 signifikant häufiger nach Blasensprengung auftreten als vor dieser Maßnahme $[1,6,19]$. Dips vom Typ 1 kommen bei ungleichmäßiger Kopfkompression des Feten oder bei vorübergehendem Nabelschnurgefäßverschluß während eincr Wehe vor.

Zweck dieser Arbeit ist es, typische Herzfrequenzmuster des Feten unter der Geburt auszuarbeiten, wenn die Eihäute bis zur zweiten Geburtsphase intakt bleiben, sowie die Häufigkeit der Dips vom Typ 1 bei fortgeschrittener Geburt (Muttermund über $5 \mathrm{~cm}$ ) zu vergleichen bei Frauen mit intakter Fruchtblase einerseits und bei Frauen mit gesprungener Fruchtblase andererseits.

Die Studie wurde an 37 schwangeren Frauen ohne bekanntgewordene Komplikationen, mit spontanem rcchtzeitigem Wehenbeginn und normalem Fortschreiten der Geburt durchgeführt, ohne daß Wehenmittel, analgetische oder andere Medikamente erforderlich wurden. Bei 17 dieser Geburten wurde die Fruchtblase bei einer Muttermundsweite von $5 \mathrm{~cm}$ gesprengt (frühe Blasensprengung). Bei den anderen 20 Geburten blieb die Fruchtblase mindestens . bis zur vollständigen Eröffnung des Muttermundes erhalten. Die Entscheidung für eine frühe Blasensprengung wurde willkürlich getroffen. Bei allen $37 \mathrm{Ge}$ burten wurden der intrauterine Druck und die fetale Herzfrequenz graphisch aufgezeichnet. Solange die Eihäute intakt waren, wurde die fetale Herzfrequenz mittels Ultraschall aufgezeichnet. Es besteht kein signifikanter Unterschied zwischen beiden Gruppen bezüglich Geburtsdauer sowie Geburtsgewicht, Kopfmaße und Apgar-Werte der Neugeborenen (Abb. 1, 2, 3, 4).

Die Häufigkeit der Dips vom Typ 1 innerhalb einer Gruppe wurde durch die Prozentzahl der Wehen ausgedrückt, die zu einem Dip vom Typ 1 führten. Für diese Berechnung wurden die Wehen während der einzelnen Geburten jeder Gruppe zusammengezählt. Die Signifikanz des Unterschiedes zwischen zwei Gruppen bezüglich des Auftretens von Dips des Typ 1 wurde durch einen nichtparametrischen statistischen Test ermittelt.

Die Häufigkeit der Dips vom Typ 1 ist niedrig oder gleich null, wenn die Eihäute bis wenige Minuten vor der Entbindung intakt bleiben (Abb. 5 und 6). Wenn der Blasensprung spät erfolgt, bei eingetretenem kindlichen Kopf, so sind die Dips vom Typ 1 sehr häufig (Abb. 7). Nach einer frühen Blasensprengung, bevor noch der Kopf eingetreten ist, sind die Dips vom Typ 1 selten (Abb. 8-A); mit Eintreten des Kopfes nimmt die Häufigkeit zu (Abb. 8-B).

Der Einfluß dreier Faktoren auf die Häufigkeit der Dips vom Typ 1 wurde quantitativ untersucht: 1) Zustand der Fruchtblase (intakt oder gesprungen); 2) Höhenstand des kindlichen Kopfes (vor oder nach dem Eintreten ins kleine Becken); 3) Nabelschnurschlinge um den Hals des Feten (ja oder nein).

Während der ersten Geburtsphase (Abb. 9) sind die Dips vom Typ 1 signifikant seltener in der Gruppe mit intakter Fruchtblase (3\%) gegenüber jener mit früher Blasensprengung (21\%). Dieses Ergebnis stimmt mit der Hypothese überein, daß die Wasserhülle den Kopf des Feten vor einer ungleichmäßigen Kompression während der Wehe schützt.

Ein ähnliches Ergebnis fand sich auch bei der Untersuchung der Häufigkeit der Dips vom Typ 1 in der Geburtsphase vor Eintreten des Kopfes (Abb. 10-A) und ebenfalls in der Phase nach dem Kopfeintritt (Abb. 10-B). In beiden Fällen sind die Dips vom Typ 1 bei intakter Fruchtblase signifikant seltener als bei früher Blasensprengung. Diese Beobachtung legt die Vermutung nahe, daß der schützende Effekt der Vorblase sowohl vor wie nach dem Kopfeintritt wirksam ist.

In der Gruppe mit gesprungener Fruchtblase ist das Auftreten dieser Dips signifikant häufiger nach dem Kopfeintritt gegenüber der Phase vor dem Eintreten des Kopfes (Abb. 11-B), was deutlich macht, daß das Eintreten in Abwesenheit der Vorblase stark die Ausbildung der Dips vom Typ 1 begünstigt. Ein ähnlicher Vergleich innerhalb der Gruppe mit intakter Fruchtblase zeigt keinen signifikanten Unterschied vor und nach dem Kopfeintritt, was die schützende Wirkung der intakten Fruchtblase selbst bei eingetretenem Kopf bestätigt (Abb. 11-A). In keiner Gruppe wurde ein signifikanter Einfluß der Nabelschnurumschlingung um den Hals des Feten auf die Häufigkeit der Dips vom Typ 1 festgestellt (Abb. 12).

Die Häufigkeit der Dipy vom Typ II ("späte Dezeleration") ist in allen Gruppen sehr gering (unter $2 \%$ ), was dem ausgezeichneten Zustand aller Neugeborenen entspricht. Die Dips vom Typ II wurden in dieser Arbeit nicht weiter analysiert.

Aus klinischen Beobachtungen [1, 6, 13, 19, 20] geht hervor, daß Dips vom Typ I wahrscheinlich mit einer ungleichmäßigen Kompression und Deformierung des fetalen Kopfes einhergehen, was zu EEG-Veränderungen, zerebralem Geburtstrauma und zu neurologischen Folgeerkrankungen führen kann [7, 21, 15]. Tierversuche $[12,14]$ zeigen, daß die Kompression des fetalen Kopfes die Blut- und Sauerstoffversorgung des Gehirns vermindert, wodurch es zu EEG-Veränderungen und einem Anstieg des Vagus-Tonus kommt mit raschem Abfall der fetalen Herzfrequenz.

All diese Tatsachen lassen es ratsam erscheinen, die allgemeine geburtshilfliche Praxis der Blasensprengung in der frühen Eröffnungsperiode als eine Routinemaßnahme der Geburtsleitung neu zu überprüfen.

Schlüsselworte: Vorblase, Kompression des fetalen Kopfes, Dips - Typ I und Typ II, fetale Herzfrequenz, Geburtsüberwachung, Nabelschnur, Blasensprung, Wehen. 


\section{Résumé}

La fréquence cardiaque foetale au cours du travail d'accouchement avec les membranes intactes et rompues

Il est déjà connu que la production de Dips Type I par les contractions utérines est significativement plus haute après l'amniotomie qu'avant la même. Les dips type I sont attribués à l'inégal compression de la tête foetale ou à l'occlusion des vaisseaux ombilicaux pendant les contractions utérines.

Le but de ce travail c'est d'établir le patron de FCF (Fréquence Cardiaque Foetale) au cours de l'accouchement, quand l'amnios reste intact jusqu'à la dilatation complète du col. Aussi, de faire la comparaison entre la présence de dip type I au cours du travail (avec une dilatation cervicale plus grande que $5 \mathrm{~cm}$ ) entre les femmes qui ont leurs membranes intactes et des autres auquelles on les a rompues. L'étude est fait sur 37 femmes enceintes qui n'ont pas eu des complications pendant la grossesse, qui ont commencé spontanéement leurs travaux à terme sans avoir besoịn d'oxytocine, d'analgésie ou d'autres médicaments.

Dans 17 femmes les membranes sont rompues artificiellement au moment que la dilatation du cervix est arrivée à $5 \mathrm{~cm}$ (amniotomie précoce). Dans les autres 20 femmes les membranes restaient intactes jusqu'à la dilatation complète du cervix. La décision de rompre les membranes est faite à l'hasard. Dans tous les 37 travaux d'accouchement on a régistré la pressure amniotique et la fréquence cardiaque foetale. Quand les membranes sont intactes, la FCF est registrée en utilisant les ultrasons. Il n'y a eu aucune différence significative entre les deux groupes dans la duration du travail et le poids de naissance, le perimètre de la tête et le score d'Apgar des nouveaux nés (Figs. 2, 3, 4).

L'incidence des dips type I dans un groupe est indiquée par le percentage des contractions utérines qui produisent des dips type I. Pour ce calcul toutes les contractions enregistrées dans un groupe sont sommées ensemble. La signification des différences dans l'incidence des dips type I entre les deux groupes est déterminée par un test statistique non paramétrique.

Quand les membranes restent intactes jusqu'à quelques minutes avant l'accouchement l'incidence des dips type $I$ est basse ou presque nulle (Figs. 5 et 6 ). Si la rupture se produit tardivement, quand la tête foetale est déjà engagée, on registre une grande quantité de dips type I après la rupture (Fig. 7). Après l'amniotomie précoce, faite avant l'engagement de la tête, l'incidence des dips type I est basse (Fig. 8-A); quand la tête s'engage l'incidence augmente (Fig. 8-B).

L'influence des trois facteurs sur l'incidence des dips type I est analysée quantitativement: 1) Etat des membranes (intactes ou rompues); 2) situation de la tête foetale (avant ou après l'engagement), et 3 ) circulaire du cordon umbilical autour du col (présent ou absent).

Pendant la période de dilatation cervicale (Fig. 9) 1'incidence des dips type $I$ est significativement plus basse dans le groupe des travaux avec des membranes intactes $(3 \%)$ que dans le groupe avec amniotomie précoce (21\%). Ce résultat est d'accord avec l'hypothèse que la poche des eaux protège la tête foetale de la compression reçue pendant les contractions utérines.

On rencontre un résultat semblable aussi en étudiant l'incidence des dips type I dans la période avant l'engagement de la tête (Fig. 10-A) qu'après cet engagement (Fig. 10-B). Dans les deux conditions l'incidence de dips type I est significativement plus basse dans les travaux avec des membranes intactes que dans les travaux avec une amniotomie précoce. Ce fait suggère que l'effet protecteur de la poche des eaux est présent avant et après l'engagement de la tête.

Aux travaux avec les membranes rompues, l'incidence est significativement plus haute après que la tête est engagée qu'avant cet engagement (Fig. 11-B). Cela indique qu'en absence de la poche des eaux l'engagement favorise la production des dips type I. Une même comparaison faite dans le groupe avec les membranes intactes ne démontre pas de différence significative avant et après l'engagement de la tête. Ce fait suggère que la protection donnée par les membranes intäctes est présente même quand la tête est engageé (Fig. 11-A).

On n'a pas rencontré d'influence significative du circulaire du cordon ombilical autour du col sur l'incidence des dips type I dans les deux groupes étudiés (Fig. 12).

L'incidence des dips type II (ralentissement tardif, [10]) est très basse (moins que $2 \%$ ) dans les deux groupes, d'accord avec la très bonne condition de tous les nouveaux nés. Les dips type II ne seront plus analysés dans ce travail.

L'évidence obtenue de l'observation clinique $[1,6,13,19$, 20] indique que les dips type. I peuvent être associés à la compression non-uniforme et à la déformation de la tête foetale, laquelle peut produire des alterations à l'EEG [7], des lésions cérébrales [21] et des séquelles neurologiques [15]. Des recherches faites dans des animaux $[12,14]$ démontrent que la compression de la tête foetale reduit le flux du sang et l'apport d'oxygène au cerveau, lesquels sont les responsables des altérations de l'EEG. Aussi, cette compression augmente le tonus du vague avec la conséquente chutte de la FCF.

Tous ces facteurs nous font conseiller la reconsidération de la pratique obstétricale, très commune, de rompre les membranes artificiellement tôt dans la période de dilatation cervicale, comme une méthode de routine dans la conduite du travail d'accouchement.

Mots-clés: Fréquence cardiaque foetale, membranes (intactes et rompues), Amniotomie précoce, dip I, compression de la tête foetale. 


\section{Bibliographie}

[1] Althabe, O., G. Aramburu, R. L. Schwarcz, R. CALDEYrobarcia: Influence of the rupture of membranes on compression of the fctal head during labor. In: Perinatal Factors Affecting Human Development, Pan American Health Organization, Scientific Publication No. 185, Washington D. C. 1969

[2] Berdaguer, P., R. Alvarez, H. Sabatino, J. M. Belizan, M. Magaña, J. R. Lopez Canales, R. Schwarcz: Comparación de la contractilidad uterina $y$ del progreso del parto en casos con membranas ovulares íntegras y rotas. V Reunión de la Asociación Latinoamericana de Investigaciones en Reproducción Humana (A. L. I. R. H.); Scientific Publication No. 87, Buenos Aires 1972

[3] Bainbridge, M. N., W. C. W. Nixon, C. N. Smyth: The effect of rupture of membranes upon length of labor. J. Obstet. Gynaec. Brit. Emp., 65 (1958) 189

[4] Brotanek, V., J. Hodr: Fetal distress after artificial rupture of membranes. Amer. J. Obstet. Gynec. 101 (1968) 542

[5] Brotanek, V., C. H. Hendricks, T. Yoshida: Importance of changes in uterine blood flow in initiation of labor. Amer. J. Obstet. Gynec. 105 (1969) 535

[6] Caldeyro-Barcia, R., R. L. Schwarcz, O. AltHABE: Effects of rupture of membrane on fetal heart rate pattern. Int. J. Gynaec. Obstet. 10 (1972) 169

[7] Garcia Austr, E.: Effects of uterine contractions on the EEG of the human fetus during labor. In: Perinatal Factors Affecting Human Development, Pan American Health Organization, Scientific Publication No. 185, Washington D. C. 1969

[8] Fedrick, J., N. R. ButLer: Certain causes of Neonatal Death. Cerebral Birth Trauma. Biol Neonate 18 (1971) 321

[9] Friedman, E. A., M. R. Sachtleben: Amniotomy and the course of labor. Obstet. and Gynec. 22 (1963) 755

[10] Hon, E. H., E. J. Quilligan: The classification of fetal heart rate. II. A revised working classification. Conn. Med. 31 (1967) 779

[11] Lindgren, L.: The causes of foetal head moulding in labour. Acta obstet. gynec. scand. 39 (1960) 46

[12] Mann, L. I., A. Carmichaed, S. Duchin: The effect of head compression on FHR, brain metabolism and function Obstet. and Gynec. 39 (1972) 721
[13] Mendez-Baudr, C., J. J. Poseiro, G. Arellano Hernandez, M. A. Zambrana, R. CaldeyroBARCIA: Effects of atropine on the heart rate of the human fetus during labor. Amer. J. Obstet. Gynec. 85 (1963) 1033

[14] Misrahy, G. A., A. V. Beran, J. F. Spradley, V. P. Garwood: Fetal brain oxygen. Amer. J. Physiol. 199 (1960) 959

[15] Muller, P. F., H. E. Campbell, W. E. Grahiam, H. Brittain, J. A. Fitzzgerald, M. A. Hogan, V. H. Muller, A. H. Rittenhouse: Perinatal factors and their relationship to mental retardation and other parameters of development. Amer. J. Obstet. Gynec. 109 (1971) 1205

[16] Niswander, K. R., M. Gordon: The women and their pregnancies. Coll. Perinatal Study, Nat. Institute Neurological Diseases and Stroke, W. B. Saunders Co. Philadelphia 1972

[17] Praagh, I. V., Ch. H. Hendricks: The effect of amniotomy during labor in multiparas. Obstet. and Gynec. 24 (1964) 258

[18] Poma-Herrera, P., A. Webster, L. G. Keith: The effect of amniotomy on progress in the first stage of labor: a retrospective study. The Chicago Medical School Quarterly, 29 (1970) 184

[19] Schwarcz, R. L., G. Strada Saenz, O. Althabe, J. Fernandez Funes, R. Caldeyro-Barcia: Pressure exerted by uterine contractions on the head of the human fetus during labor. In: Perinatal Factors Affecting Human Development, Pan American Health Organization. Scientific Publication No. 185, Washington D. C. 1969

[20] Schwarcz, R. L., S. Konichezky: Latin American Collaborative Study on the influence of membranes upon labor and the newborn. Progress Report presented to Panamerican Health Organization and to the Collaborating Groups. Latin American Center of Perinatology and Human Development, Montevideo 1973

[21] Schwartz, P.: Birth injury of the newborn. Hafner Publishing Co., New York 1961

[22] Sreger, A.: Nonparametric Statistics for the Behavioral Sciences. McGraw Hill Book Co. Inc., New York 1956

[23] Wetrich, D. W.: Effect of amniotomy upon labor. Obstet. and Gynec. 35 (1970) 800

Dr. Ricardo Schwarcz

Centro Latinoamericano de

Perinatología y Desarrollo Humano

Casilla de correo 627

Montevideo, Uruguay 